Original Research Article

\title{
Hematological profile of children with sickle cell Disease in special reference to body iron stores
}

\author{
Muley $\mathbf{P}^{1}$, Agrawal $\mathbf{R}^{2}$, Pathak $\mathbf{S}^{3}$, Trivedi $\mathbf{B}^{4}$ \\ ${ }^{1}$ Dr. Prasad Muley, Professor, SB. K. SMIRC, Sumandeep Vidyapeeth Vadodara, Gujrat, India, ${ }^{2}$ Dr Rohit \\ Agrawal, Assistant Professor, T.S. Mishra Medical College, Anaura Lukhnow, ${ }^{3}$ Dr Sunil Pathak Assistant \\ Professor, SB. K. SMIRC Sumandeep Vidyapeeth Vadodara, Gujrat, India, ${ }^{4}$ Dr Bhadra Trivedi, Pediatric \\ Cardiologist Wockhard Hospital Mumbai, Maharashtra, India.
}

Address for Correspondence- Dr Rohit Agrawal, Assistant Professor, T.S. Mishra Medical College Anaura Lukhnow, Email: crystalcage@gmail.com

\begin{abstract}
Introduction: Sickle cell anemia is a genetic disorder commonly seen in rural population of western and central India. Being an important cause of hemolytic anemia, repeated blood transfusions are frequently required for the sickle cell anemia cases. Few studies have exclusively addressed hematological profile of sickle cell disease patients. This study was planned to study the hematological profile of children with special reference to body iron stores. Methods: This was a prospective observational study carried out in department of pediatrics S.B.K.S MIRC. All the confirmed cases of children diagnosed with sickle cell disease or sickle $\beta$ thalassemia were subjected to complete hematological analysis in special reference to body iron store by evaluation of serum iron, TIBC, \% transferrin saturation and serum ferritin to find out total body iron store. Results: About 110 patients were included in the study. In our study low MCV values were seen in $60.4 \%$ of patients, low $\mathrm{MCH}$ values in $84.9 \%$ of patients while MCHC was normal in $94.3 \%$ of patients. Serum iron levels showed normal values in majority of patients $(94.3 \%$ ) while transferrin saturation was low in $62.3 \%$ patients thus showing the discrepancy on correlating both values for diagnosis of iron deficiency. Conclusion: Out of various parameters for diagnosis of iron status in SCD-SS patients, low $\mathrm{MCV}, \mathrm{MCH}$, Serum iron level and transferrin saturation more consistently associated with iron deficient state.
\end{abstract}

Key words- Sickle cell disease, Serum iron, \% transferrin saturation, TIBC, Anemia

\section{Introduction}

Sickle Cell Disease (SCD) is one of the most common childhood-onset, single-gene disorder affecting approximately 80,000 people in India. Worldwide approximately 300,000 infants are born with Sickle Cell Disease. Sickle cell trait is most common in individuals originating from Africa, South America, Central America, the Caribbean islands, the Mediterranean, India, and Saudi Arabia [1].

Sickle cell disease results from an inherited hematological disorder involving defects in normal haemoglobin production. Sickle cell syndromes include sickle cell anaemia (SCD-SS),

Manuscript received: $16^{\text {th }}$ May 2017

Reviewed: $26^{\text {th }}$ May 2017

Author Corrected: $4^{\text {th }}$ June 2017

Accepted for Publication: $12^{\text {th }}$ June 2017
Haemoglobin SC (SCD-SC), Haemoglobin S beta thalassemia (SCD- $\beta$-thal) and Sickle cell Trait (SCT-SA).

Sickle cell disease (SCD-SS) is the most common and severe variant. It results when an individual inherits a substitution of valine for the normal glutamic acid in the $\beta$ - globin chain of haemoglobin from both parents [2]. This substitution alters the haemoglobin molecule so it crystallizes and deforms the red cell into a sickle shape when the haemoglobin loses oxygen. Both parents must be carriers of the defected gene in order for the transmission of the disease to occur. Children who only inherit one sickle cell gene have an SCD-AS pattern, the A representing a normal haemoglobin gene. This is also referred to 
as sickle cell trait. Overt symptoms rarely occur in this variant [3]. The clinical manifestations of sickle cell anemia result from increased blood viscosity and vascular obstruction by deformed sickled red cells. These clinical difficulties are related to the loss of oxygen to necessary tissue areas, in that the flexibility of the red blood cells is lessened causing a decrease in their ability to carry oxygen.

This causes vascular occlusions, hemorrhages, infarctions and ischemic necrosis of tissues and organs throughout the body causing several complications including recurrent vaso-occlusive crises and associated stroke, splenic sequestration crisis, aplastic crisis, infections, bone damage (i.e. hip necrosis), jaundice, leg ulcers, priapism, delayed growth, fatigue and painful episodes $[2,4]$.

With the realization that patients with sickle cell anemia may lead relatively normal lives with $\mathrm{Hb}$ levels between 7.0 and $9.0 \mathrm{~g} / \mathrm{dl}$, regular blood transfusions are no longer used in the management of these patients. However, blood transfusions may be necessary for complications such as an 'aplastic' or 'sequestration' crisis. Among the hazards of repeated blood transfusion is accumulation of iron as the human body has no effective physiological mechanism for excreting excess iron [5]. Therefore, in conditions where transfusions are frequently indicated, exogenous iron can accumulate, circulate as non - transferrin bound iron, enter tissues, form reactive oxygen species and result in end organ damage.

It has been reported that iron deficiency anemia is uncommon in individuals with sickle cell disease because of availability of an adequate iron source potentially from increased red cell turnover and from blood transfusion [6,7]. It is believed that iron released by hemolysis is available for reutilization and that iron deficiency is uncommon in these conditions.

However, contrary to the previous belief few studies reported that iron deficiency was common than expected in untransfused sickle cell anemia cases [8,9]. Iron deficiency anemia often goes unnoticed because the sickle cell disease patients are already anemic. Iron deficiency in sickle cell patients may result in lowering the intracellular haemoglobin concentration and this may ameliorate sickling [5]. The patients with sickle cell disease do not acquire excessive iron burden during the first two decades of life.

The gold standard for assessing liver iron stores in the absence of cirrhosis is the hepatic iron content determined by liver biopsy and quantification with atomic absorption spectrometry. Noninvasive methods include blood tests (Serum Iron, ferritin, Percentage Transferrin saturation and Total Iron binding Capacity) and imaging techniques (MRI based techniques).Sickle cell disorder has remained a neglected field of research in our country and magnitude of the problem has never been appreciated. This study was carried out with the main purpose to assess the hematological profile of children in special reference to body iron status of patients with sickle cell disease.

\section{Materials and Methods}

Study design- Prospective observational study

Setting- Department pediatrics S.B.K.S MIRC rural teaching hospital

Inclusion \& exclusion criteria- children between the age of 6 months to 18 years were eligible for the study. All diagnosed and suspected cases of sickle cell disease reporting to the hospital were included in the study. Prior consent was taken from parents/ guardian before enrollment and ascent was sought from adolescents. Children with age less than 6 months, with concomitant chronic infective diseases (like chronic osteomyelitis, HIV etc.), with history of blood transfusion in the preceding 3 months or patients not consenting for participation were excluded from the study.

All the patients with positive solubility test and strongly suspected clinically but sickle negative were subjected to high performance liquid chromatography (HPLC) for confirmation and to differentiate sickle cell disease from other variants such as sickle cell trait, Sickle Beta thalassemia etc. The patients showing the presence of band representing $\mathrm{HbS}$ in the $\mathrm{Hb}$ electrophoresis were further categorized as Sickle Cell Disease, Sickle cell Disease with thalassemia and sickle cell trait depending upon $\mathrm{HbS}$ and $\mathrm{HbA} 2$ levels. All the patients having $\mathrm{HbS}$ more than $50 \%$ were enrolled in the study for further analysis. Patients with sickle cell disease and sickle cell disease with 
thalassemia were further investigated for Serum Iron, Serum ferritin, Total iron Binding capacity (TIBC) and Percentage Transferrin Saturation (\% TFR). All Children were investigated for complete blood picture (Hemoglobin, Total leucocyte count, Platelet Count, RBC Indices). All the tests were carried out in institution's laboratory. Institutional ethics committee's permission was taken before conducting the study.
Detailed history general examination as well as systemic examination was carried out and was recorded.

Statistical analysis - All the was collected data were analyzed using SPSS software and described in the form of percentages, mean and Standard deviation

\section{Result}

200 patients were screened in the study out of which $110(55 \%)$ who tested positive for sickling by the solubility test were subjected to hemoglobin electrophoresis. Out of the total 200 patients, 26 patients tested positive for SCD-SS, 27 for SCd- B thallsemia and 57 for sickle cell trait. Mean age of the enrolled patients were 10.2 years and $73.6 \%$ were males.

As patients with sickle cell trait remain asymptomatic most of the time or have minor manifestation only, patients with SCD-SS and SCD- $\beta$-thalassemia only were included in further analysis. Distribution of patients was studied with respect to hematological profile. (Table-1) and no significant difference was observed between the two groups. In both group the MCV and $\mathrm{MCH}$ was low suggestive of probable underlying iron deficiency specially in SCD - SS group.

Table-1: Distribution according to hematological profile.

\begin{tabular}{|c|c|c|}
\hline Hematological parameter & SCD-SS (26) & SCD- $\boldsymbol{\beta}$ - Thal (27) \\
\hline Hemoglobin $(\mathrm{gm} \%)$ & $8.7 \pm 1.5$ & $8.5 \pm 1.4$ \\
\hline TLC(count/mm3) & $10,200 \pm 4160$ & $11,800 \pm 4360$ \\
\hline Platelet count $(\mathrm{L} / \mathrm{mm} 3)$ & $2.6 \pm 0.75$ & $2.84 \pm 0.95$ \\
\hline PCV(vf) & $24.04 \pm 4.2$ & $24.68 \pm 4.1$ \\
\hline MCV(fl) & $69.00 \pm 8.3$ & $65.32 \pm 6.5$ \\
\hline MCH(pg/cell) & $23.45 \pm 2.2$ & $22.13 \pm 1.9$ \\
\hline MCHC(g/dl) & $34.16 \pm 2.0$ & $34.29 \pm 3.9$ \\
\hline RDW(\%) & $20.48 \pm 3.0$ & $19.68 \pm 2.8$ \\
\hline Normal reticulocyte count & $5(19.2 \%)$ & $5(18.5 \%)$ \\
\hline High reticulocyte count & $21(80.8 \%)$ & $22(81.4 \%)$ \\
\hline
\end{tabular}

Hb-Hemoglobin, HCT hematocrit, TLC- Total Leucocyte Count,, PCV Packed Cell Volume,, MCV mean cell volume, $\mathrm{MCH}$ mean cell hemoglobin, $\mathrm{MCHC}$ mean cell hemoglobin concentration, RDW Red Cell Distribution Width, HbF fetal hemoglobin,

Distribution of various hemoglobin variants in our study population is described in Table 2. No significant difference was observed in the levels of $\mathrm{HbF}$ and $\mathrm{HbS}$ amongst the two groups but the HbA2 level was significantly different with higher levels being observed in Sickle thalassemia patients.

Table-2: Mean of $\mathrm{HbS}, \mathrm{HbA2}, \mathrm{Hb} \mathrm{F}$ in SCD-SS and SCD $\beta$ - thal

\begin{tabular}{|c|c|c|}
\hline Mean & SCD-SS(n=26) & SCD- $\boldsymbol{\beta}$ Thal(n=27) \\
\hline $\mathrm{HbS}$ & $75.36 \%$ & $75.67 \%$ \\
\hline $\mathrm{HbF}$ & $20.28 \%$ & $17.93 \%$ \\
\hline $\mathrm{HbA} 2$ & $2.78 \%$ & $4.34 \%$ \\
\hline
\end{tabular}

On comparing parameters of body iron store in the two groups, serum iron was marginally more in SCD-SS $(61.9 \pm 31.9)$ as compared to SCD- $\beta$ thal $(58.7 \pm 40.1)$, whereas Serum ferritin was significant higher in SCD- $\beta$ thal (244.5) as compared to SCD-SS (61.9 \pm 31.9$)$ 
Table-3: Mean body iron stores in patients with SCD-SS and SCD- $\beta$ thal.

\begin{tabular}{|c|c|c|}
\hline & $\begin{array}{c}\text { SCD-SS } \pm \text { SD (range) } \\
{[\mathbf{n}=\mathbf{2 6}]}\end{array}$ & $\begin{array}{c}\text { SCD- } \boldsymbol{\beta} \text {-thal } \pm \text { SD (range) } \\
(\mathbf{n}=\mathbf{2 7})\end{array}$ \\
\hline Serum Iron $(\boldsymbol{\mu g} / \mathbf{d l})$ & $61.9 \pm 31.9$ & $58.7 \pm 24.3$. \\
\hline TIBC $(\boldsymbol{\mu g} / \mathbf{d l})$ & $268.8 \pm 47$ & $250 \pm 47.9$ \\
\hline Serum Ferritin(ng/ml) & $195 \pm 22$ & $244.5 \pm 34$ \\
\hline \%TFR & $28.39 \pm .9$ & $31.4 \pm 12.8$ \\
\hline
\end{tabular}

TIBC - Total Iron Binding Capacity, TFR -Transferrin Saturation

Serum iron, TIBC were with in normal limits while \% Transferin saturation were low. Few records of serum ferritin was too high probably it may be acting as acute inflammatory marker in patient admitted due to various reasons.

\section{Discussion}

Sickle cell disease is a chronic hemolytic disease that results from a single base pair change, thymine for adenine at the 6 th codon of $\beta$-globin chain leading to polymerization of deoxygenated hemoglobin S and distorting the shape of the cell.

A total of 53 patients, majority of whom were males $(73.6 \%)$ were included in the study. Similar findings were seen by Khan et.al [10]. This could be explained by increased chances of severe sickness and crisis in males or gender bias in tribal community, resulting in health care seeking behavior favoring males.

Most of the patients were in the age group of 7-12 years as also seen in study by Sahu et al [11]. However Kar et.al. found minimum age of presentation to be 6 months. Probable reason for patients reporting at a later stage in our study might be initial treatment at primary level before reporting to our tertiary care hospital [12].

In our study, out of total 110 patients screened positive for sickle cell, 57(51.8\%) were heterozygous and 53(48.2\%) were homozygous. Mandout et..al in 2009, in a cross section analysis of tribal patients attending hospitals or mobile clinics in Rajasthan, showed that the prevalence of sickle cell anemia was $9.2 \%$ out of which $0.8 \%$ were homozygous and $8.4 \%$ were heterozygous [13]. Probable reason for this difference is that our study was hospital based.

In our study out of 53 patients, 26(49.1\%) patients were diagnosed with SCD-SS while 27(50.9\%) with SCD- $\beta$ Thal. Our finding differs from Kar et al who found $91.9 \%$ cases of SCd-SS and $8.1 \%$ cases of SCd $\beta$ - thal [12]. The mean fetal hemoglobin level in our study in patients with SCD-SS was $20.28 \%$ and in those with SCD$\beta$ Thal. was $17.93 \%$. The mean HbF level in this study correlates with study done by Walke et al (16.79\%) [14]. However, in a study done by Kaur et al, the mean $\mathrm{HbF}$ varied between 9.7-13.5\%. the distribution of values could be attributed to inclusion of adult patients in their study [15].

All the patients were found to be anemic. The mean hemoglobin concentration was $8.2 \mathrm{gm} \%$ in patients with SCD-SS and $8.5 \mathrm{gm} \%$ in patients with SCD- $\beta$ thal. The reticulocyte count was found to be high in majority of patients $(81.1 \%)$ suggesting chronic response to hemolysis. Similar findings were seen in study done by Khan et al [10] and Juwah et al [16].

In our study low MCV values were seen in $60.4 \%$ of patients, low $\mathrm{MCH}$ values in $84.9 \%$ of patients while MCHC was normal in $94.3 \%$ of patients. Haddy et.al. [17] Showed low Hb, decreased MCV, $\mathrm{MCH}$ and $\mathrm{MCHC}$ values in patients with sickle cell disease who showed response to iron supplements. Davis et al [18] found low MCV and $\mathrm{MCH}$ in his patients and raised the suspicion of iron deficiency anemia. Walke et al [14] found low $\mathrm{MCV}, \mathrm{MCH}$, $\mathrm{MCHC}$ and raised reticulocyte count.

Contrary to expectation despite sickle cell disease being hemolytic anemia, serum iron levels showed normal values in majority of patients $(94.3 \%)$ while transferrin saturation was low in $62.3 \%$ patients thus showing the discrepancy on correlating both values for diagnosis of iron deficiency. However, Lulla et al showed that low transferrin saturation 
was most indicative of iron deficiency anemia and an increase in transferrin saturation represented the most consistent indicator of response to iron supplementation [19]. The discrepancy between values of transferrin saturation and iron levels in our study could be explained from the fact that serum iron as a measure of iron deficiency has several limitations including wide normal of variations, errors from ingestion, diurnal variation and falls during mild or transient infections.

TIBC levels were found to be normal in 28(52.8\%) patients and low in 25(47.2\%) patients. Similarly ferritin was found to be normal in 19 (35.8\%) patients and high in $34(64.2 \%)$ patients. Olbuyde et al [20] found significantly higher levels of ferritin when sickle cell anemia was complicated by chronic osteomyelitis.

High ferritin levels and low TIBC levels do not correlate with iron deficient state as both are affected during acute illnesses. TIBC decreases while serum ferritin increases during acute illnesses (as ferritin is an acute phase reactant). In our study most of the patients reported to hospital with some or other acute illness, thus explaining higher serum ferritin values. Thus, serum ferritin cannot be used as a sensitive marker for analysis of estimation of body iron stores in sickle cell anemia or sickle cell disease unless the patient is in steady state.

Vichinsky et al [12] reported that serum ferritin levels below $25 \mathrm{ng} / \mathrm{ml}$ and low MCV to be the most useful screening tests. Rao et al [27] found an excellent inverse correlation between serum ferritin and serum transferrin and a significant positive correlation between serum ferritin and transferrin saturation, bone marrow iron and a history of blood transfusion. Guyatt et al [28] found serum ferritin radioimmunoassay to be the most sensitive test for same purpose. Khan et al [14] concluded that serum ferritin was more sensitive indicator than serum iron, TIBC, and transferrin saturation.

Thus, based on present and previous studies available, out of various parameters for diagnosis of iron status in SCD-SS patients, low MCV and $\mathrm{MCH}$ are more consistently associated with iron deficient state. Such patients need to be further evaluated on long term basis after giving trial of iron therapy. The limitation of the study was the small study group which was not enough regarding the actual status of body iron among patients with sickle cell disease. The confounding effect of underlying illness of serum ferritin used to assess iron stores also added to problems.

We propose further studies with larger sample population in this area. More specific tests and serial estimations of iron status are required for better definition of iron deficiency status in sickle cell disease. Response to therapeutic iron trial can be used as a diagnostic criterion for iron deficiency in sickle cell disease.

\section{Abbreviations}

SCD- Sickle cell disease, SCD-SS Sickle cell

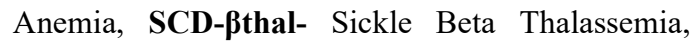
SCD-AS- Sickle Cell Trait, Hb- Hemoglobin, HPLC- High Performance Liquid Chromatography, HbS- Sickle Hemoglobin, HbA2Hemoglobin A2 Level, TIBC- Total Iron Binding Capacity, \%TFR- \% Transferrin Saturation, TLCTotal Leucocyte count, RBC- Red blood cell, MCV- Mean corpuscular volume, MCH- Mean corpuscular hemoglobin, MCHC- Mean corpuscular hemoglobin concentration, PCVPacked cell Volume, SD- Standard Deviation, RDW- Red cell Distribution width., HbF- Fetal hemoglobin

Funding: Nil, Conflict of interest: None initiated, Perission from IRB: Yes

\section{References}

1. Bernadette Modell \& Matthew Darlison, Global epidemiology of haemoglobin disorders, Bulletin of the World Health Organization, 2008;86:480-48.

2. The Georgia Comprehensive Sickle Cell Center at Grady Health System, The Sickle Cell Foundation of Georgia, Inc., Emory University School of Medicine, Department of Pediatrics. (1997). Sickle cell information center. http://www.scinfo.org/sicklept.htm

3. Shapiro BS. The management of pain in sickle cell disease. Pediatr Clin North Am. 1989 Aug; 36 (4):1029-45.

4. Wood, R.A., Fosarelli, P., Hudak, M., Lake, A., \& Modlin, L. Pediatrics. Philadelphia: Lipincott. 1989. 
5. Hussain MA, Davis LR, Laulicht M, Hoffbrand AV. Value of serum ferritin estimation in sickle cell anaemia. Arch Dis Child. 1978 Apr;53 (4): 319-21.

6. Erlandson ME, Walden B, Stern G, Hilgartner MW,Wehman J, Smith $\mathrm{CH}$, et al. Studies on congenital haemolytic syndromes IU. Gastrointestinal absorption of iron. Blood $1962 ; 19: 359$.

7. Cohen A, Schwartz E. Excretion of iron in response to deferoxamine in sickle cell anemia. J Pediatr. 1978 Apr;92(4):659-62.

8. Vichinsky E, Kleman K, Embury S, Lubin B. The diagnosis of iron deficiency anemia in sickle cell disease.Blood.1981Nov;58(5):963-8.

9. Mohanty D, Mukherjee MB, Colah RB, Wadia M, Ghosh K, Chottray GP, Jain D, Italia Y, Ashokan K, Kaul R, Shukla DK, Muthuswamy V. Iron deficiency anaemia in sickle cell disorders in India. Indian J Med Res. 2008 Apr; 127 (4):366-9.

10. Khan Y, Thakur AS, Mehta R, Kundu RK, Agnihotram G. Hematological profile of sickle cell disease: a hospital based study at CIMS, Bilaspur, Chhattisgarh. IJABPT 2010;1(2): 717-721.

11. Sahu T, Sahani NC, Das S, Sahu SK. Sickle cell anaemia in tribal children of gajapati district in south orissa. Indian Journal of Community Medicine 2003;28(4).

12. Kar BC. Sickle cell disease in India. J Assoc Physicians India. 1991 Dec;39(12):954-60.

13. Mandot S, Khurana VL, Sonesh JK. Sickle cell anemia in Garasia tribals of Rajasthan. Indian Pediatr.2009Mar;46(3):239-40.Epub 2009Jan 1.
14. Walke VA, Walde MS. Haematological study in sickle cell homozygous and heterozygous children in the age group 0-6 years. Indian J Pathol Microbiol. 2007 Oct;50(4):901-4.

15. Kaur M, Das GP, Verma IC. Sickle cell trait \& disease among tribal communities in Orissa, Madhya Pradesh \& Kerala. Indian J Med Res. 1997 Mar;105:111-6.

16. Juwah AI, Nlemadim EU, Kaine W. Types of anaemic crises in paediatric patients with sickle cell anaemia seen in Enugu, Nigeria. Arch Dis Child. 2004 Jun;89(6):572-6.

17. Haddy TB, Castro O. Overt iron deficiency in sickle cell disease. Arch Intern Med. 1982 Sep;142(9):1621-4.

18. Davies S, Henthorn J, Brozović M. Iron deficiency in sickle cell anaemia. J Clin Pathol. 1983 Sep;36(9):1012-5.

19. Lulla RR, Thompson AA, Liem RI. Elevated soluble transferrin receptor levels reflect increased erythropoietic drive rather than iron deficiency in pediatric sickle cell disease. Pediatr Blood Cancer. 2010 Jul 15;55(1):141-4. doi: 10. 1002/pbc. 22471 .

20. Oluboyede OA, Usanga EA, Lukanmbi FA, Ajayi OA. Evaluation of serum ferritin levels and other hematological parameters in a Nigerian population. J Natl Med Assoc. 1983 September; 75(9): 885-889.

21. Rao KR, Patel AR, McGinnis P, Patel MK. Iron stores in adults with sickle cell anemia. J Lab Clin Med. 1984 May;103(5):792-7.

22. Guyatt GH, Oxman AD, Ali M, Willan A, McIlroy W, Patterson C. Laboratory diagnosis of iron-deficiency anemia: an overview. J Gen Intern Med. 1992 Mar-Apr;7(2):145-53.

\section{How to cite this article?}

Muley P, Agrawal R, Pathak S, Trivedi B. Hematological profile of children with sickle cell Disease in special reference to body iron stores. J PediatrRes.2017;4(06):370-375.doi:10.17511/ijpr.2017.i06.04. 